\title{
Discourses of Legal Certainty in Execution of Administrative Court Decision
}

\section{Nyoman Martana; Putu Ade Hariestha Martana; Kadek Agus Sudiarawan; Bagus Hermanto}

\author{
Faculty of Law Udayana University
}

email:degust.ugm@gmail.com

\begin{abstract}
After the enactment of the Law of Government Administration implied to regulation concerning the execution of the Administrative Court Judgment. Some pro-cons academic and practice discourses, arguing that the enactment of the Law of Government Administration is the culminating point from the limited role of the Administrative Court on enforcing the administrative law and the argument that the regulation of the Law of Government Administration contains various ambiguities norms in concern with implementation in the Administrative Procedural Law System. This study aims to analyze and discuss concerning regulation of the provisions of the Administrative Court Ruling execution, constrains in judgment execution and the legal certainty for the justice seekers in the provisions of the Administrative Court Ruling execution after the enactment of the Law of Government Administration. This paper is using normative and empirical method. The data that using consisted of primary and secondary data, were analyzed using qualitative methods. This study results is presented in a descriptive analysis paper.
\end{abstract}

Keywords:Legal Certainty; Administrative Court Ruling; The Law of Administrative Court; The Law of Government Administration.

\section{INTRODUCTION}

The provisions of Article 24 Paragraph (2) of the 1945 Constitution of the Republic of Indonesia (hereinafter referred to as the 1945 Constitution of the Republic of Indonesia) stipulates that judicial power is exercised by a Supreme Court and the judicial body underneath it within the General Judiciary, the Religious Courts, the Military Courts, the Administrative Court, and by a Constitutional Court. ${ }^{1}$ This provision confirms that Indonesia as a state of law as affirmed Article 1 Paragraph (3) of the 1945 Constitution of the Republic of Indonesia. ${ }^{2}$ This means that the law must be a guideline, and must be obeyed and also upheld by citizens and the state. In addition, in the implementation of duties and authorities, the government must be guided by the law and be able to account for these tasks. ${ }^{3}$

${ }^{1}$ This provision was born after the reform and amendment of the 1945 Constitution of the Republic of Indonesia between 1999 - 2002. Vide Jr., Dominic J. Nardi. (2018). Can NGOs Change the Constitution? Civil Society and the Indonesian Constitutional Court. Contemporary Southeast Asia, ISEAS - Yusof Ishak Institute, 40(2), p. 253. doi: https://doi.org/10.1355/cs40-2d p. 103.

${ }^{2}$ Yusa, I Gede, et al. (2016). Hukum Tata Negara: Pasca Perubahan UUD NRI 1945. Malang: Setara Press,

${ }^{3}$ Hayat, Hayat. (2015). Keadilan sebagai Prinsip Negara Hukum: Tinjauan Teoritis dalam Konsep Demokrasi. Padjadjaran: Jurnal Ilmu Hukum (Journal of Law), Universitas Padjadjaran, 2(2), p. 388. doi: https://doi.org/10.22304/ pjih.v2n2.a10 
The prerequisites of the Indonesian rule of law are marked by the existence of an administrative or state administrative court, which is regulated through Law No. 5 of 1986 jo. Law No. 9 of 2004 jo. Law No. 51 of 2009 concerning State Administrative Court (hereinafter referred to as State Administrative Court Law) as the basis for the birth of administrative justice in the Indonesian legal system.

The existence of the State Administrative Court has urgency in relation to review the validity of government actions, namely the issuance of Administrative Decision. ${ }^{4}$ The Administrative Decision which is detrimental to a civil person or legal entity as the object of a lawsuit for a state administrative dispute in accordance with the absolute competence of the Administrative Court. This is potentially a preventive measure for government actions that have the potential to be incompatible with the laws and/or general principles of good governance. On the other hand, this can be interpreted as legal protection for the people. The provisions of Article 47 of the Administrative Court Law regulate the absolute competence of the Administrative Court to examine, decide upon and resolve state administrative disputes.

The administrative dispute is a dispute arising in the field of state administration between a person or a legal entity with a state administrative agency or agency both at the center and in the region, as a result of the issuance of a state administration decision, including an employment dispute based on statutory regulations, as stipulated in Article 1 number 4 of the Administrative Court Law. Whereas, the meaning of a Administrative Decision is a written stipulation issued by a state administration body or official containing legal action on state administration which is based on concrete, individual and final laws and regulations that lead to legal consequences for a person or legal entity civil law as referred to in the provisions of Article 1 number 3 of the Administrative Court Law.

The existence of institutions with the authority to review the validity of government actions is becoming increasingly important in the welfare state. Philosophically, the principle of the rule of law of Indonesia is a dynamic rule of law state or the principle of the welfare state, which emphasizes in the welfare state, ${ }^{5}$ state interference is so extensive and profound through government actions in the life of the community in the context of service to the community to achieve the welfare of the people, as one of the country's goals.

The results of review of whether or not a governmental action in the form of a Administrative Court Judgment is expected to be truly carried out in order to achieve

${ }^{4}$ Bedner, Adriaan. (2013). Indonesian Legal Scholarship and Jurisprudence as an Obstacle for Transplanting Legal Institutions. Hague Journal on the Rule of Law, Cambridge University Press, 5(2), pp. 260 - 261. doi: https:// doi.org/10.1017/S1876404512001145

${ }^{5}$ Yusa, I Gede, \& Hermanto, Bagus. (2017). Gagasan Rancangan Undang-Undang Lembaga Kepresidenan: Cerminan Penegasan dan Penguatan Sistem Presidensiil Indonesia. Jurnal Legislasi Indonesia, Kementerian Hukum dan Hak Azasi Manusia RI, 14(3), p. 316. 
openness and guarantee access to justice for the people. ${ }^{6}$ The emphasis is on realizing legal certainty to realize legal protection for the people from government actions in carrying out government functions. ${ }^{7}$ This also means that the Administrative Court for the community becomes an oversight body for government actions that always upholds the dignity and dignity of the people, and is always guided by the law. ${ }^{8}$

Legal certainty is provided through the state administrative court which results in a court decision. In the case of granting a claim by the plaintiff by stating that the administrative decision of the defendant is declared invalid or invalid, a court decision can determine the obligations that must be carried out by the defendant namely the revocation of the relevant administrative decision, also the revocation accompanied by the issuance of a new state administrative decision, or issuance of state administrative decisions in the case of a lawsuit referring to Article 3 of the Administrative Court Law. This obligation can be accompanied by the imposition of compensation or rehabilitation. In this case, the decision of the Administrative Court can also give certain rights to the disputing parties, especially the plaintiff. The rights granted through a court decision should be enjoyed properly by the plaintiff through the court's decision.

In the Administrative Court, court decisions that are inkracht van gewisjde or have legal force still contain the nature of erga omnes namely the court's decision applies to anyone and is not limited to the parties to the dispute..$^{9}$ If the party who gets the right cannot properly enjoy his rights arising based on a court decision, it means that there has been a denial of justice, and a denial of legal certainty and legal protection of the people. ${ }^{10}$

Decisions of the Administrative Court give rise to subjective rights on the one hand and on the other hand give rise to obligations for the other party to fulfil those subjective rights. For the sake of legal certainty, the rights arising as a result of the decision must be enjoyed by those entitled to through a predetermined mechanism. ${ }^{11}$ The way to obtain subjective rights arising from decisions or those contained in condemnatoir decisions is done through requests for implementation of decisions/execution of decisions. In the

\footnotetext{
${ }^{6}$ Butt, Simon. (2013). Freedom of Information Law and Its Application in Indonesia: A Preliminary Assessment. Asian Journal of Comparative Law, Cambridge University Press, 8(1), p. 12. doi: https://doi.org/10.1017/ S2194607800000879

${ }^{7}$ Bunga, Marten. (2018). Tinjauan Hukum Terhadap Kompetensi Peradilan Tata Usaha Negara dalam Menyelesaikan Sengketa Tanah. Gorontalo Law Review, Universitas Gorontalo, 1(1), p. 44. doi: https://doi. org/10.32662/golrev.v1i1.155

'Sudarsono. (2011). Pilihan Hukum dalam Penyelesaian Sengketa Tata Usaha Negara di Pengadilan Tata Usaha Negara. In I Gede Yusa (Ed.), Demokrasi, HAM \& Konstitusi: Perspektif Negara - Bangsa untuk Menghadirkan Keadilan; "Kado untuk Sang Guru Prof. Dr. I Dewa Gede Atmadja, S.H., M.S. Malang: Setara Press, p. 241.

${ }^{9}$ Yuslim. (2015). Hukum Acara Peradilan Tata Usaha Negara. Jakarta: Sinar Grafika, pp. 5 - 6.

${ }^{10}$ Effendi, Maftuh. (2014). Peradilan Tata Usaha Negara Indonesia Suatu Pemikiran ke Arah Perluasan Kompetensi Pasca Amandemen Kedua Undang-Undang Peradilan Tata Usaha Negara. Jurnal Hukum dan Peradilan, Mahkamah Agung RI, 3(1), p. 26. doi: http://dx.doi.org/10.25216/JHP.3.1.2014.25-36

${ }^{11}$ Suhariyanto, Budi. (2019). Urgensi Kriminalisasi Contempt of Court untuk Efektivitas Pelaksanaan Putusan Peradilan Tata Usaha Negara. Jurnal Konstitusi, Mahkamah Konstitusi RI, 16(1), p. 198. doi: https://doi. org/10.31078/jk16110
} 
Administrative Court Law, the implementation of decisions is regulated in the provisions of Article 115 through Article 119.

The court's ruling on the new Administrative Court has executive power and can be implemented/executed after obtaining permanent legal force. ${ }^{12}$ Copies of decisions which are inkracht van gewisjde or have permanent legal force by the Registrar of Courts are delivered to the parties who are litigants. There is an obligation of the defendant to obey and implement the contents of the court's decision in good faith and responsibility. If the defendant does not intend to implement the decision in the case of a decision concerning the obligation for the defendant to revoke the Decision that has been issued, then within 4 (four) months after the court's decision which is inkracht van gewisjde, the disputed decision has no legal force anymore, and no more execution attempts are needed. This is because by automatically passing the four month deadline, the disputed decision has no legal force.

When the court ruling establishes an obligation for the defendant to revoke the administrative decision of the sued state and issue a new state administrative decision, and within a period of three months the defendant does not implement it, the plaintiff has the right to submit an application to the Chair of the State Administrative Court to order the defendant party to carry out the court decision order. Based on the request of the plaintiff, the Chair of the Court orders the defendant to carry out the order in the Court's decision. If the order in the verdict is not carried out, the defendant will be subject to a number of forced efforts in the form of payment of a sum of forced money and/or administrative sanctions..$^{13}$ This is done or not depends on the defendant himself. If after the imposition of the forced attempt the verdict is not carried out also by the defendant, this will be announced through the local print media by the Registrar. However, problems related to the non-implementation of court decisions that give certain rights to the plaintiff, opening opportunities for the defendant to be reluctant to implement the ruling and in the case of court decisions that are not possible to impose its implementation has implications for the absence of legal certainty.

The birth of Law No. 30 of 2014 concerning Government Administration (hereinafter referred to as the Government Administration Law) then made various changes related to material laws and formal laws that apply to administrative law. ${ }^{14}$ The Government Administration Law in addition to regulating material legal provisions, also provides formal legal arrangements that apply to the state administrative procedural system. In fact, this regulation has caused various confusions by various related parties (especially judges) in

\footnotetext{
${ }^{12}$ Rumadan, Ismail. (2012). Problematika Eksekusi Putusan Pengadilan Tata Usaha Negara. Jurnal Hukum dan Peradilan, Mahkamah Agung RI, 1(3), p. 438. doi: http://dx.doi.org/10.25216/JHP.1.3.2012.435-462

${ }^{13}$ Lubna, Lubna. (2015). Upaya Paksa Pelaksanaan Putusan Pengadilan Tata Usaha Negara dalam Memberikan Perlindungan Hukum kepada Masyarakat. Jurnal Ius: Kajian Hukum dan Keadilan, Universitas Mataram, 3(1), pp. 166 - 167. doi: http://dx.doi.org/10.12345/ius.v3i7.205

${ }^{14}$ Hadjon, Philipus M. (2015). Peradilan Tata Usaha Negara dalam Konteks Undang-Undang No. 30 Th. 2014 tentang Administrasi Pemerintahan. Jurnal Hukum dan Peradilan, Mahkamah Agung Rl, 4(1), pp. 53 - 54. doi: http://dx.doi.org/10.25216/JHP.4.1.2015.51-64
} 
the administration of administrative law in the Administrative Court. Some forms of changes in the regulation of the Government Administration Law are related to the regulation of the expansion of the meaning of state administrative decisions as objects of state administration disputes, arrangements related to positive fictitious decisions, the authority to adjudicate the abuse of authority by the government apparatus, arrangements related to administrative efforts, not governing the limitation of the amount of compensation and including special arrangements related to the implementation of the decision becomes an urgency to be comprehensively studied after the entry into force of the Government Administration Law.

Based on the background description, this paper focuses on the subject of discussion, namely legal certainty in the execution of the Decree of the Administrative Court both through the regulation of the Administrative Court Law and the Government Administrative Law, by raising several formulations of the problem namely how the execution provisions decisions, constraints faced, and how legal certainty for the community in the provisions of the execution of the decision of the Administrative Court after the enactment of the Government Administration Law.

The issue through legal research is an interesting and important issue in the legal system of the Administrative Court. The initiative raised the legal issues in this study which is intended as an effort to strengthen the state administrative procedural law system specifically to measure the strength of the execution of decisions and answer various confusion arising from all elements in the state administrative procedural law system specifically regarding the regulation of provisions related to the execution of the Administrative Court decision State Enterprises are good at two different laws namely the Administrative Court Law and the Government Administrative Law.

\section{METHOD}

This paper is based on a normative writing methodology format with the image of the law as a prescriptive discipline,${ }^{15}$ focusing on the law as a norm ${ }^{16}$ or a norm system or hierarchy of laws and regulations ${ }^{17}$ and using empirical juridical writing methods. The merger of the two methods in order to complete the normative study through empirical research in the form of field research that is focused on the second problem, namely on the Denpasar Administrative Court with non-probability sampling technique with a purposive type on the Chairperson of Denpasar Administrative Court and Judge on the State Administrative Court

\footnotetext{
${ }^{15}$ Choudhury, Nafay. (2017). Revisiting Critical Legal Pluralism: Normative Contestations in the Afghan Courtroom. Asian Journal of Law and Society, Cambridge University Press, 4(1), p. 231. doi: https://doi.org/10.1017/ als.2017.2

${ }^{16}$ Sonata, Depri Liber. (2014). Metode Penelitian Hukum Normatif dan Empiris: Karakteristik Khas dari Metode Meneliti Hukum. Fiat Justisia: Jurnal IImu Hukum, Universitas Lampung, 8(1), pp. 24 - 25. doi: https://doi. org/10.25041/fiatjustisia.v8no1.283

${ }^{17}$ Petroski, Karen. (2013). Legal Fictions and the Limits of Legal Language. International Journal of Law in Context, Cambridge University Press, 9(4), p. 488. doi: https://doi.org/10.1017/S1744552313000268
} 
Denpasar through interviews. While the use of normative research with the study of legislation, literature and scientific journals and relevant official publications to answer the first and third problems. The results of this study are presented in a descriptive analytical scientific paper.

\section{ANALYSIS AND DISCUSSION}

\section{A. Provisions for Execution of Judicial Decisions in Administrative Court after the Enactment of Administrative Court Law}

\section{The Procedure for Execution of the Administrative Court Decision based on the Administrative Court Law}

In connection with the execution of the decision at the Administrative Court, it can be specifically explained that, in disputes that are examined, decided and tried by the Administrative Court, there are sometimes conditions where the related agency/official as the party being punished is reluctant to carry out the contents of the decision voluntarily. If the contents of the decision are not carried out voluntarily, then an execution must be carried out. In civil procedural law, the legal basis for the implementation of the decision (execution) is regulated in HIR or Rbg, namely Article 195 to Article 224 HIR or Article 206 to Article 258 Rbg; Article 1033 Rv, Law No. 48 Year 2009 concerning Judicial Power as well as various laws and regulations whose substance is more specific in nature, such as the Civil Code (concerning mortgages) and the Mortgage Rights Act (concerning the execution of mortgage rights).

Both HIR and Rbg contain detailed provisions relating to the implementation of the decision (execution), from the beginning of the execution process until the end, that is, until the contents of the court's decision are fulfilled. In Articles 195 to Article 224 of the HIR or Article 206 to Article 258 of the RBg, provisions concerning warning/reprimand have been regulated; confiscation of execution; fulfillment of achievement: emptying the disputed object, submitting the disputed object, auction, payment; and hostage-taking (gijzeling).

The legal basis for the implementation of court decisions (executions) in the state administrative court procedural law is regulated in Article 115 through Article 121 of the State Administrative Court Law. Provisions for the execution of decisions in the state administrative court procedural law are very few, even summary when compared with the provisions of the implementation of court rulings in civil procedural law. The law does not contain provisions regarding who ordered the execution, who led the execution and how to realize the contents of the decision which was inkracht van gewisjde. ${ }^{18}$ Regarding the obligations mandated by the law to the Chairperson

${ }^{18}$ Soleh, Mohammad Afifudin. (2018). Eksekusi terhadap Putusan Pengadilan Tata Usaha Negara yang Berkekuatan Hukum Tetap. Mimbar Keadilan, Universitas 17 Agustus 1945 Surabaya, 11(1), pp. 23 - 24. doi: https://doi.org/10.30996/mk.v0i0.1604 
of the State Administrative Court, is the obligation to oversee the execution of the execution as regulated in Article 119 of the Administrative Court Law.

That "coercion from public officials" to realize the contents of the decision there is no provision governing it, or it can be said there is a legal vacuum. It is also unclear who should order the "coercion", and who is leading the "coercion". Article 116 Paragraph (3) of the Administrative Court Law regulates the word "ordered", but in the context of the plaintiff's request, which is stated when the defendant is determined to carry out the obligations as has been affirmed in the provisions of Article 97 Paragraph (9) letter b and letter $\mathrm{c}$, also after 90 (ninety) working days the obligation is not carried out, the plaintiff submits an application to the head of the court in the form of an order from the court to the defendant to implement the court's decision.

The decision of a state administrative court that requires implementation is a condemnatory decision because it imposes an obligation to be carried out for the defeated State Administration Agency or Officer. Article 97 Paragraph (8) of the Administrative Court Act essentially states if the lawsuit is granted, while in the ruling it can determine the existence of obligations that must be carried out by the State Administration Agency or Officer who issued the Decision. This provision is the starting point for the issuance of obligations that must be done by the defendant. Article 97 Paragraph (9) of the State Administrative Court Law determines the obligations imposed on the defendant, namely the revocation of the relevant Decision; or revocation of the relevant Decision and issuing a new Decision; or issuance of Decisions in the case of a lawsuit based on Article 3.

The three types of liabilities are basically two liabilities, namely revocation of decree and issuance of new decree. Both of them constitute the substance of the basic decision which is condemnatoir. An additional condemnatory decision is the obligation to pay compensation as Article 97 Paragraph (10) of the Administrative Court Law and the obligation regarding rehabilitation as Article 97 Paragraph (11) of the Administrative Court Law. Based on Article 97 there are 5 (five) items in the content of the decision which is condemnatoir, namely three obligations which include the principal and two obligations which include additional proposals. If the obligation in the decision is not carried out by the defendant on a voluntary basis, it is possible to carry out an execution because the condemnatory decision has an executive power.

\section{a. Revocation of Administrative Decision}

After the decision of the state administration court whose sentence is conditional is handed down, the defendant namely the state administration body or official is obliged to carry out the contents of the decision. In its implementation, the defendant may be reluctant to implement the contents of 
the decision voluntarily, so the implementation of the contents of the decision should be carried out by force through execution.

Related to the execution of the obligation to revoke a state administration decision, contained in Article 97 Paragraph (9) letter (a) of the Administrative Court Law. The procedure for carrying out the execution of the decision containing the obligation to revoke this decision is regulated in Article 116 Paragraph (2) of the Administrative Court Law, and after 60 (sixty) working days of the court's decision the inkracht van gewisjde is received but by the defendant not carried out then the disputed decision has no legal force anymore. Therefore, no other efforts are needed from the court, because the state administrative decision automatically loses its legal force which is commonly referred to as automatic execution. ${ }^{19}$ Although not revoked, but the decision has no legal force anymore.

Regarding the revocation of the decision based on a court decision which is inkracht van gewisjde, for example, in the case of a plaintiff who faces a decision that is burdensome, for example related to the dismissal of an employee or an order to demolish a building. If the plaintiff's lawsuit is granted by the court and the defendant is sentenced to revoke the said decision, the plaintiff will have obtained his rights only after the stipulated deadline, which is four months after the judicial decision which has permanent legal force is submitted to the defendant.

\section{b. Issuance of New Administrative Decision}

The obligation to issue a new decree is regulated in two different articles, namely Article 97 Paragraph (9) letter b and Article 97 Paragraph

(9) letter $c$ of the Administrative Court Law. There is a difference between the two articles, Article 97 Paragraph (9) letter b contains two obligations, namely revoking the plaintiff's decision and issuing a new decision, and Article 97 Paragraph (9) letter $\mathrm{c}$ contains the obligation of the defendant to issue a decision if the lawsuit is based on Article 3 paragraphs (1) through (3) of the Administrative Court Law, which essentially states that if the defendant does not issue a decision, whereas it is the defendant's obligation, then it is equated with the State Administrative Decree, both in terms of not issuance of the decision is requested over the time period or not specified time period but after four months from receipt of the request, the defendant is considered to have refused to issue the decision in question.

${ }^{19}$ Sunge, Maisara. (2009). Efektivitas Eksekusi Putusan Pengadilan Tata Usaha Negara. Jurnal Inovasi, Ikatan Mahasiswa Pascasarjana dan Alumni Gorontalo di Bandung, 6(4), p. 81. 
Article 97 Paragraph (9) letter c of the Administrative Court Law regulates the issuance of negative fictitious state administrative decisions. In a case like this the defendant actually did nothing, but by law this situation is the same as the defendant issued a state administration decision containing the rejection. The reason is that the defendant as the public service provider is obliged to serve every community request that is his obligation, if neglected, even though he has not done anything, the law considers that the defendant has issued a decision to reject the request or a negative fiction..$^{20}$

An applicant who feels aggrieved can file a lawsuit over the state of silence of the state administration or administrative officer, because the attitude of silence is equated with the decision to reject the petition. If the petition is filed according to procedure, the court can punish the defendant to issue the intended decision or petition, but with the Government Administration Act there is a drastic change because the Government Administration Act adopts a new principle that is the positive fictive principle as opposed to the fictitious principle negative.

The execution of the decision on the inkracht van gewisjde which contains the obligation to issue state administrative decisions refers to the provisions of Article 97 paragraphs (9) letters b and c and Article 116 paragraphs (3) through Paragraph (6) of the Administrative Court Law. The provisions basically stipulate that in the event that the defendant is determined to have to carry out obligations regarding the revocation of the plaintiff's decision and issue a new decision, and then after 90 (ninety) working days the obligation is not carried out, the plaintiff has the right to submit an application to the Chair, the court has requested that the court order the defendant to carry out the decision, which is then by the Chair of the Court with a warrant ordering the defendant to implement the decision. If the defendant does not obey the Chief Justice's order regarding the implementation of the decision on the defendant party, that is, the body or official concerned will be subject to payment of an amount of forced money and/ or administrative sanctions. In the event that the defendant is reluctant to also carry out, the defendant is announced through the local print media by the court clerk, and the head of the court is required to submit to the President to order the official to implement the decision and the representative body of the people in order to carry out the supervisory function. Although in this provision, there are provisions on the amount of forced money, types of administrative sanctions, and the procedures for its implementation in Article 116 Paragraph (7) of the 
Administrative Court Law mandated to be regulated by law, but until now the mandate of the article has not been implemented.

Observing the provisions of the execution of court decisions as referred to in Article 116 Paragraph (3) to Paragraph (6) of the Administrative Court Law, basically the execution in the Administrative Court emphasizes self respect ${ }^{21}$ and legal awareness of the defendant's party regarding the contents of the decision to carried out voluntarily without any coercive efforts (dwang middelen) that can be felt and imposed by the court against the defendant. ${ }^{22}$

When compared with the implementation of civil court executions whose decisions are condemnatoir (ordered, punish), then the difference is clearly seen. There are a number of differences in the execution of executions in civil and state administrative courts. The first difference is in the role of the Chair of the Court and the executing agency, and the second difference in the existence of sanctions. However, the execution process in the State Administrative Court Law contains shortcomings, as the implication of legal normativisation in the Act does not yet stipulate sanctions for non-compliance of the defendant who does not implement the administrative decision. ${ }^{23}$ Another difference is that in the state administrative procedure law, there is no real execution as a civil court, but administrative execution, so that the defendant must implement the contents of the decision itself. ${ }^{24}$

Regarding the role of the Chairperson of the District Court in the execution process, he played the role of "ordering" and "leading" the execution. In this function, the Chairperson of the District Court is in the execution process since there is an application for execution. The Chair of the District Court in ordering and leading the execution is based on the provisions in the HIR/RBg and is assisted by institutions such as clerks and clerks.

In the state administration procedural law, the Chairperson of the Court may order the execution in response to the claimant's request based on Article 116 Paragraph (3) of the State Administrative Court Law. Based on this article the plaintiff won can request the court chairman to order the defendant to carry out the decision. According to Himawan Krisbiyantoro, a judge at the Denpasar

\footnotetext{
${ }^{21}$ Untoro, Untoro. (2018). Self-Respect dan Kesadaran Hukum Pejabat Tata Usaha Negara Menuju Keadilan Pandecta: Jurnal Penelitian IImu Hukum (Research Law Journal), Universitas Negeri Semarang, 13(1), pp. 41 - 42. doi: https://doi.org/10.15294/pandecta.v13i1.7856

${ }^{22}$ Gusman, Delfina. (2010). Efektifitas Pelaksanaan Upaya Paksa Putusan Pengadilan Tata Usaha Negara yang telah Berkekuatan Hukum Tetap. Masalah-Masalah Hukum, Universitas Diponegoro, 39(3), pp. 223 \& 228. doi: https://doi.org/10.14710/mmh.39.3.2010.221-230

${ }^{23}$ Harahap, Zairin. (2009). Hukum Acara Peradilan Tata Usaha Negara. Jakarta: PT. Raja Grafindo Persada, pp. $153-154$.

${ }^{24}$ Yulius, Yulius. (2018). Diskursus Lembaga Eksekusi Negara dalam Penegakan Hukum di Indonesia. Jurnal Hukum Peratun, Mahkamah Agung Rl, 1(1), p. 15.
} 
Administrative Court, that the position of Chairperson of the Administrative Court is as a supervisor of executions and is passive, there needs to be initiative from the plaintiff to submit an application if the defendant does not want to implement the contents of the decision. The plaintiff's initiative is needed because the court does not know whether the contents of the decision have been carried out or not. And according to Gayuh Rahantyo, a judge at the Denpasar Administrative Court, if not based on the request of the plaintiff, the Chairperson of the State Administrative Court will issue a decision addressed to the defendant's superior so that the contents of the decision are carried out by the defendant.

Because the implementation of the State Administrative Court Decision which is inkracht van gewisjde cannot be carried out by any institution other than the defendant, and the position of the Chairperson of the Court is only to oversee the implementation of the decision which has been inkracht and the absence of an executing support institution such as a bailiff in civil court, the execution is only based on self respect or personal awareness of the defendant. Although forced efforts can be made in the form of payment of a sum of forced money and/or administrative sanctions, but as has been described many problems are associated with the implementation of the forced effort. The main problem is the unclear regulation regarding the nominal forced money, the types of administrative sanctions, and how the process of forced and paying payments and/or administrative sanctions are in fact mandated in the provisions of Article 116 Paragraph (7) of the State Administrative Court Law.

\section{State Administrative Court Execution Provisions According to Government Administrative Law}

Provisions for the execution of decisions on State Administrative Court are regulated in the Administrative Court Law. In its development with a background to improve governance, also provide legal protection for citizens and government officials themselves, and to realize good governance, the Government Administration Law was enacted. ${ }^{25}$

The Government Administration Act is the legal basis for the administration of government in enhancing good governance and creating a better, transparent and efficient bureaucracy. In addition, the regulation of the Government Administration Law as a material legal basis for testing the decisions or actions of government officials based on legislation and general principles of good governance, and shifting the old paradigm to the new paradigm is the paradigm of public service in

\footnotetext{
${ }^{25}$ Mawardi, Irvan. (2016). Paradigma Baru PTUN: Respon Peradilan Administrasi terhadap Demokratisasi. Yogyakarta: Thafa Media, p. 75.
} 
the administration of government that continues to develop along with openness broader access to public information, and emphasizes the responsibilities of governments oriented to public services.

For this reason, the existence of the Government Administration Law is placed as one of the pillars of bureaucratic reform and good governance, through arrangements for the implementation of government administration by government agencies and/or officials who are always guided by the general principles of good governance and provisions statutory regulations, as an embodiment of the principle of legality in the implementation of government administration.

The academic paper on the Government Administration Act outlines the urgency of the Government Administration Act both philosophically, sociologically and juridical, which is clearly illustrated in the consideration of the Government Administration Act which mentions several foundations for the formation of the Government Administration Act including to encourage improvement in the quality of government administration, government bodies and/or officials carry out their authority must be guided by general principles of good governance and the applicable laws in the framework of guaranteeing legal protection, and based on considerations to manifest good governance and based on decisions and/or actions of government officials in relation to guarantees fulfilment of community legal protection.

Various basic justifications for the birth of the Administrative Court Law do not necessarily make the birth of the Administrative Court Law accepted directly by the public and related parties, both in a position to support the promulgation of the Government Administrative Law because it is seen as a progressive step in reforming government administration However, there is a view that the promulgation of the Government Administration Law also causes confusion and overlapping regulations, especially related to procedural law which must be applied and used as a guideline for judges in examining State Administration disputes in Administrative Courts.

The presence of the Government Administration Law has brought a paradigm shift fundamentally with regard to the absolute competence of the Administrative Court, because the absolute competence of the Administrative Court which was originally limited, has been expanded. As for some changes that provide an expansion of competence in the case submission procedure in the Administrative Court. As for some forms of expansion of competencies regulated in the Government Administration Law including ${ }^{26}$ in terms of expanding the meaning

\footnotetext{
${ }^{26}$ Wairocana, I Gusti Ngurah, Sudiarta, I Ketut, Layang, I Wayan Bela Siki, Sudiarawan, Kadek Agus, \& Pramana, I Gede Pasek. (2019). The Expansion of Administrative Decision Meaning Based on Government Administration Law: A Dispute Submission Process Approach. Jurnal Magister Hukum Udayana (Udayana Master Law Journal), Universitas Udayana, 8(1), pp. 20 - 26. doi: https://doi.org/10.24843/JMHU.2019.v08.i01.p02
} 
of the Administrative Decision; Competence of the Administrative Court for review whether or not there is an element of abuse of authority at the stage of issuance of the Administrative Decision; also to decide on the object of a positive fictitious dispute; then level one in the case of prosecuting after administrative effort; and to try or grant a claim for compensation, without limitation of a certain amount.

These various expansion of competencies that were arranged after the birth of the Government Administration Act later created new problems and became a sensitive and very interesting issue for in-depth study. This arrangement of competency expansion is because it is thought to leave various theoretical problems that cause confusion in the technical implementation.

In addition to regulating various extensions of state administrative court competencies, specifically the Government Administration Act apparently also regulates certain matters whose substance is also regulated in the Administrative Court Law. Among them regarding the execution of the Administrative Court Judgment. The execution was related to problems in the administration of government. Where the problems in the administration of the government arise because the community members, individuals or civil legal entities, ${ }^{27}$ feel disadvantaged by the Administrative Decision which is in the provisions of the Government Administration Law or referred to as the State Administration Decree or the Government Administration Law. In this case, there is an expansion of the object of state administration dispute, because based on Article 1 number (9) and Article 53 Paragraph (1) of the Administrative Court Law, the object of the state administrative dispute is the Administrative Decision which must meet the criteria or elements of written form; issued by state administrative bodies or officials; contains legal actions in state administration; based on the applicable laws and regulations; concrete, individual and final; cause legal consequences for a person or legal entity.

As for the regulation of the Government Administration Law, the meaning of state administrative decisions in the form of formal actions in the form of written, or in the form of factual actions, although not written. The expansion of the object of the dispute is not only related to factual actions, in Article 87 the Law on Government Administration states that the meaning of a Administrative Decision must be interpreted inter alia as a written determination which also includes factual actions; also the decisions of bodies/institutions in the executive, legislative, judiciary and other state administration circles; based on statutory provisions and general principles of good governance; is final in a broader sense or meaning;

\footnotetext{
${ }^{27}$ Astomo, Putera. (2014). Eksistensi Peradilan Administrasi dalam Sistem Negara Hukum Indonesia. Masalah-
} Masalah Hukum, Universitas Diponegoro, 43(3), p. 370. doi: https://doi.org/10.14710/mmh.43.3.2014.363-371 
decisions that have the potential to lead to legal consequences/implications; and/ or decisions that apply to all members of the community. ${ }^{28}$

With the stipulation of the definition of state administrative decisions in Article 87 of the Government Administration Law which is included in the transitional provisions violates the rules in the formation of legislation as Appendix II number 135 of Law No. 12 of 2011 concerning the Formation of Legislation and Article 1 number 9 or Article 87 of the Administrative Court Law also contradicts Article 24A Paragraph (5) of the 1945 Constitution of the Republic of Indonesia, because Article 87 of the Government Administrative Law has veiled changes to the provisions of Article 1 number 9 of the Administrative Court Law. ${ }^{29}$

In this case, there is also a shift in understanding from the object of State Administration disputes namely the Government Administration Decree and Government Administration Acts based on the Government Administration Act are also different from the meaning set out in the State Administrative Court Law. In Article 1 number 7 of the Government Administration Law, the Government Administration Decree is a written decree issued by a Government Agency and/ or Officer in the administration of government. That the individual elements of the definition in the State Administrative Court Law are eliminated and the implication is that the change of the plaintiff in a state administrative dispute, so that the plaintiff in a state administrative dispute is not only an individual/individual who is harmed but is a community member who is harmed by an Administrative Decree Government and/or Government Administration Acts. Especially when related to the provisions of Article 87 letter e of the Government Administration Act, those who can be located as plaintiffs as parties in a state administration dispute are not only individuals who are addressed by a decision and are not limited to disadvantaged members of the community but extend to those citizens who have the potential to experiencing legal consequences due to the issuance of a decision.

The expansion of the meaning of the Administrative Decision regulated in the provisions of Article 87 of the Transition of the Law on Government Administration later gave rise to a new perspective on the State Administrative Procedure Code and caused some confusion in its implementation. ${ }^{30}$ The expansion of the meaning of the Administrative Decision in the Government Administration Act, according

\footnotetext{
${ }^{28}$ Jiwantara, Firzhal Arzhi, Adolf, Huala, Wibowo, Gatot Dwi Hendro, \& Cahyowati, R. R. (2018). The Extension of Absolute Competence of State Administrative Court after the Enactment of Act Number 30 of 2014 on Government Administration in Indonesia. Journal of Legal, Ethical and Regulatory Issues, Allied Business Academies, 21(1), pp. $3-4$.

${ }^{29}$ Wahyunadi, Yodi Martono. (2016). Kompetensi Absolut Pengadilan Tata Usaha Negara dalam Konteks Undang-Undang Nomor 30 Tahun 2014 tentang Administrasi Pemerintahan. Jurnal Hukum dan Peradilan, Mahkamah Agung RI, 5(1), p. 140. doi: http://dx.doi.org/10.25216/JHP.5.1.2016.135-154

${ }^{30}$ Yulianto, Eko. (2017). Hukum Acara dan Praktek Peradilan Tata Usaha Negara. In Pendidikan Khusus Profesi Advokat. Yogyakarta: Indonesian Advocates Association (PERADI) in collaboration with Gadjah Mada University.
} 
to Mariana Ivan Junias, Judge at the Denpasar State Administrative Court, is aimed at the context of opening the widest possible access to justice in exercising control over administrative decisions issued by government agencies/institutions or government officials. The expansion of the object of the dispute has not been accommodated through changes to the law in the field of state administrative justice or in the form of government regulations, because the expansion must be further explained in order to be able to adjust to the administration of government. ${ }^{31}$ In addition to regulating the aforementioned matters, the Government Administration Act also regulates in summary terms the execution of a state administration court decision which is not carried out voluntarily by the defendant. Institutions related to execution as explained earlier are also regulated in the Administrative Court Law in the form of forced money (dwangsom) and administrative sanctions, as well as the provisions regarding announcements in print media and submissions to the president so that he wants to carry out the contents of the decision. Provisions regarding executions in the Government Administration Act are regulated in Chapter XII regarding administrative sanctions. Article related to the imposition of administrative sanctions related to the non-implementation of the contents of the said state administrative court decision is Article 53 Paragraph (6) of the Government Administrative Law governing Government Agencies and/ or Officers must determine the Decree in the context of implementing the Court's decision no later than 5 (five) working days since the decision. This provision is related to the positive fictive principle adhered to by the Government Administration Law which is indeed regulated in Article 53 of the Government Administration Act.

It is an obligation for the Agency and/or Government Official to determine and/or make a Decision and/or Action on the existence of a request from the public. Such decision and/or action must be taken within the period stipulated in the legislation or if the time period is not regulated, referring to the provisions of Article 53 Paragraph (2) of the Government Administration Law, no later than ten working days after the application is received in full. If there is no response beyond this time period, then based on a positive fictive principle, the request is considered granted. As a legal basis for requesting the defendant to establish/make a decision or action as requested, the community members have the right to appeal to the court to obtain a decision to accept the request. Upon this application, the court must decide within a maximum period of twenty one working days after the date of the application to the court. If the court decides that the request is accepted then based on Article 53 Paragraph (6) of the Government Administration Act, within a

${ }^{31}$ Putrijanti, Aju. (2015). Kewenangan serta Obyek Sengketa di Peradilan Tata Usaha Negara Setelah Ada UU No. 30/2014 tentang Administrasi Pemerintahan. Masalah-Masalah Hukum, Universitas Diponegoro, 44(4), p. 430. doi: https://doi.org/10.14710/mmh.44.4.2015.425-430 
maximum of five working days after the decision is decided, the government must determine the decision to implement the court's decision.

In the Government Administration Act for defendants who do not comply with the contents of court decisions in accordance with Article 53 Paragraph (6) are threatened with administrative sanctions. These administrative sanctions are regulated in Article 80 Paragraph (2) of the Government Administration Act, where the threat of violation of Article 53 Paragraph (6) is moderate administrative sanctions. What is meant by moderate administrative sanctions as stipulated in Article 81 Paragraph (2) of the Government Administration Act namely forced payment or compensation; temporary dismissal with or without obtaining office rights. These sanctions are sanctions that are basically imposed on state administrative officials or their positions, and are not directly related to government administrative decisions, so that there will be no change without the willingness of the body or institution authorized to issue the decision.

\section{Constraints in Execution of Judicial Decisions in State Administration after the Entry into force of the Law on Government Administration}

After the Government Administrative Law came into force, the execution of the judicial decision on the state administration must have experienced obstacles. The obstacle faced is precisely because of the contradictions between the regulation of the Government Administration Act and the State Administrative Court Law. Constraints faced are mainly related to legal certainty for the enactment of the positive fictive principle adhered to by the Government Administration Act which is the opposite of the negative fictive principle adhered to by the State Administrative Court Law.

The negative fictitious principle is regulated in the provision of Article 3 of the State Administrative Court Law, which basically stipulates that if the defendant party, namely an agency/institution/government official, has the obligation to issue a decision and they will not issue the decision requested within the stipulated time period on related legislation or if not regulated, based on Article 3 Paragraph (3) the law is limited to only 4 (four) months, then the silence of the Agency/Institution/ Officer is the same as a State Administration Decree. The State Administration Decree is defined as a decision on the rejection of the application submitted.

Basically, the negative fictive principle is based on the silent attitude of the official/agency/institution upon a request to issue a decision, but the official/agency/ institution does not issue the said decision. The official silence is then assumed that the official/agency/institution has issued a decision but in fact never existed so it is called a fictitious decision. That the official silence means that the request is rejected, so that it is negative, so that the negative fictive principle is born. 
The negative fictive principle is the opposite of the positive fictive principle adhered to by the Government Administration Act. This positive fictive principle in Article 53 paragraphs (1) through (6) of the Government Administration Act with provisions governing the time limit for obligations in the context of establishing/ making Decisions or Actions in accordance with the law, and in legislation does not determine the time limit for such obligations, the said Government Agency/ Institution/Official is obliged to stipulate/execute Decisions and/or Actions within a limit of up to ten working days after the application has been received in full by the agency/Institution/official. If beyond this time, the Agency and/or Government Official does not determine/make a Decision or Action, the request is deemed legally granted, and then the petitioner submits the application through the Court in order to obtain a decision regarding receipt of the request. The Court is required to decide on the application no later than twenty-one working days since the application was submitted, and it is stated that government agencies/institutions/ officials must determine the decision to implement the court's decision no later than five working days after the court's decision is determined.

Basically like a negative fictive principle, this positive fictive principle is also based on the attitude of silence from officials/institutions/state administrative bodies. The difference lies in the end result, where the positive fictive principle of silence actually means that the official accepts or grants the request in question. That the positive term in the positive fictive principle is defined as acceptance or granting of a request.

The positive fictive principle then creates obstacles, how is its position with the negative fictive principle adhered to in the State Administrative Court Law. As a solution, the legal preference used, namely the lex posterior derogate legi priori principle, applies to two equal rules and regulates the same problem to determine that the latest/newer rules outperform the older rules. In the process of drafting legislation (legislative drafting), generally when there is a new rule that is set and there are certain things in the previous regulations that are still valid or declared invalid will be regulated in the transitional rules of the new law. However, in the Government Administration Law there are no rules that state explicitly that the Article 3 of the State Administrative Court Law is not related to a negative fictive Administrative Decision.

The existence of two opposing principles, both the negative fictive principle and the positive fictive principle, of course also impact on the difference in the execution of the execution. If a lawsuit based on a negative fictive principle is granted, the court determines a decision containing the State Administration Agency or Officer required to issue a State Administration Decree as requested by the plaintiff (deemed rejected on the basis of a negative fictive principle) as 
stipulated in Article 97 Paragraph (9) letter C of the Law State Administrative Court Law. If the State Administrative Agency or Officials as referred to in Article 116 Paragraph (3) of the State Administrative Court Law in 90 days are reluctant to obey the decision, the plaintiff pleads with the Chair of the State Administrative Court so that the defendant is ordered to carry out the contents of the decision. This actually does not seem to have any urgency because the Chairperson of the TUN Court is required to oversee the implementation of the TUN court's decision which has been inkracht. After the request is submitted, if the body/institution/ official still refuses to implement the contents of the new decision then he may be subject to payment of a sum of forced money and/or administrative sanctions.

Unlike the case with executions related to positive fictive principles. If the time limit provided under Article 53 Paragraph (1) and (2) of the Government Administration Act to issue a state administration decision and/or certain actions has passed, the applicant submits an application and not a lawsuit to the Administrative Court. The application is to obtain a decision on receipt of the request (not to obtain the determination as is usual in the Administrative Court application). Five days after the decision of the State Administrative Court, the Administrative Agency or Officer is determined to determine the decision to implement the decision. Only then will Article 53 Paragraph (6) of the Government Administration Act not be implemented, in this case the agency/institution/official may be subjected to moderate administrative sanctions, in the form of forced payment of money or compensation or temporary dismissal with/without obtaining office rights.

Another obstacle in the execution of the judicial decision on state administration after the enactment of the Government Administration Act is the absence of formal rules or procedural law governing the implementation of positive fictive principles. This has long been a concern of the judiciary, especially the Judges at the State Administrative Court, apparently there has been no follow-up from the legislative body to draw up formal regulations related to this matter.

The Supreme Court then took the initiative to resolve this problem by issuing a Supreme Court Regulation No. 5 of 2015 concerning Guidelines for Procedures for Obtaining a Decision on Acceptance of Requests to Obtain Decisions and/or Actions of Government Agencies or Officers (Perma No. 5/2015), issued as the embodiment of the authority of the State Administrative Court as regulated in Article 53 of the Government Administration Law, regarding the authority of the Court to examine and decide upon the receipt of an application to obtain a Decision and/or Actions of Government Agencies/Institutions/Officers. That Article 53 is the basis of implementing positive fictive principles in the State Administrative Court. Because it was considered not to provide clear guidance for 
judges in adjudicating cases related to the application of positive fictive principles, the Perma No. 5 of 2015 was then replaced by Supreme Court Regulation No. 8 of 2017 concerning Guidelines for Procedures to Obtain Decisions on Acceptance of Requests to Obtain Decisions and/or Actions Government Agency or Officials (Regulation No. 8 of 2017).

Regarding the implementation of positive fictive principles, government bodies and/or officials who are reluctant or disobey the contents of decisions related to the implementation of the principle are threatened with moderate administrative sanctions. These sanctions are imposed on state administrative officials or their positions, not directly related to the administrative decisions themselves. So another obstacle is that there will be no change without the willingness of government agencies/institutions/officials to issue the decision. In addition, the imposition of sanctions is also unclear the legal basis that becomes the reference and there are no implementing regulations. So after the Government Administration Act regarding the execution of the judicial ruling the state administration still faces many obstacles in its implementation so it does not reflect legal certainty.

\section{Legal Certainty for the Community in Provisions for Execution of Judicial Decisions in State Administration After the Entry into force of the Government Administration Act}

In carrying out the execution process, of course the ultimate goal is for a court decision to be carried out. The implementation of the decision must of course have a legal basis regulating who is authorized to order and lead the execution, who carries out the execution, and how the execution procedure is carried out.

The rule of law regarding executions in judicial bodies is very crucial. Execution is a step that justitiabelen is expected to provide justice for a case that it faces. If we talk about law enforcement, the execution process is the last step especially if the judicial decision is not heeded. Not implementing a court decision can occur in a State Administration case. However, the decision of the State Administrative Court is very dependent on legal awareness or the willingness of the officials concerned to implement the contents of the decision ${ }^{32}$ or often referred to as execution based on self respect.

The importance of execution in implementing decisions is related to one of law enforcement functions, namely legal certainty, as well as justice and expediency. Legal certainty is a guarantee for those entitled according to law to be able to obtain their rights and that a decision can be implemented, because it is a

${ }^{32}$ Rafiqi, Rafiqi. (2017). Kompetensi Pengadilan Tata Usaha Negara dalam Menyelesaikan Kasus Tanah tentang Hak Pengelolaan. JPPUMA: Jurnal IImu Pemerintahan dan Sosial Politik UMA (Journal of Governance and Political Social UMA), Universitas Medan Area, 5(2), p. 112. doi: http://dx.doi.org/10.31289/jppuma.v5i2.1207 
form of protection for the judiciary against arbitrary actions. ${ }^{33}$ The implementation of decisions is also related to the independence of the court, where the state must be able to force the government/executive to obey the contents of the court's decision and that the court must be given the authority to ensure the implementation of the contents of the court's decision. ${ }^{34}$

In a state administrative court decision based on the State Administrative Court Law, if the lawsuit is granted, then in the ruling the ruling shall stipulate an obligation that must be carried out by a com- munity/Institution/Administrative Officer as contemplated in Article 97 Paragraph (8) to (11)) State Administrative Court Law that revokes State Administrative Decree and issuance of State Administrative Decree, that these obligations may be accompanied by the imposition of compensation or rehabilitation.

Regarding the obligation of the defendant to revoke the state administration decision sued under Article 97 Paragraph (9) letter a of the State Administrative Court Law, the state administrative court law has clearly determined the execution or implementation of the court's decision. With the passage of four months after the decision of the court with legal force still sent to the defendant, so automatically the state administrative decision sued is not inkracht van gewisjde (automatic execution). In such circumstances, legal certainty for the community has been reflected, because clearly the interests of the people are guaranteed fulfilment through this automatic execution.

Regarding the obligation of the defendant to issue a state administration decision based on Article 97 Paragraph (9) letters b and $c$ of the State Administrative Court Law, it can only be done by the defendant himself. If there is no awareness and good intention from the agency/institution/official to implement the contents of the decision, so that the decision is carried out by the defendant, the Chief Justice of the Court may order the defendant to implement the decision with permanent legal force, at the request of the plaintiff as Article 116 Paragraph (3) of the Law State Administrative Court Law. The Chairman of the Court's order if related to Article 116 Paragraph (4) of the State Administrative Court Law ${ }^{35}$ even more illustrates that the execution of execution can only be carried out by the

${ }^{33}$ Wijayanta, Tata. (2014). Asas Kepastian Hukum, Keadilan dan Kemanfaatan dalam Kaitannya dengan Putusan Kepailitan Pengadilan Niaga. Jurnal Dinamika Hukum, Universitas Jenderal Soedirman, 14(2), pp. 219 220. doi: http://dx.doi.org/10.20884/1.jdh.2014.14.2.291

${ }^{34}$ Harjiyatni, Francisca Romana, \& Suswoto, Suswoto. (2017). Implikasi Undang-Undang Nomor 30 Tahun 2014 tentang Administrasi Pemerintahan terhadap Fungsi Peradilan Tata Usaha Negara. Jurnal Hukum lus Quia Iustum, Universitas Islam Indonesia Yogyakarta, 24(4), p. 608. doi: https://doi.org/10.20885/iustum.vol24.iss4. art5

${ }^{35}$ Simanjuntak, Enrico. (2014). Prospek Ombudsman Republik Indonesia dalam Rangka Memperkuat Pelaksanaan Eksekusi Putusan Peradilan Tata Usaha Negara. Jurnal Hukum dan Peradilan, Mahkamah Agung RI, 3(2), pp. 168 - 169. doi: http://dx.doi.org/10.25216/JHP.3.2.2014.163-176 
Administrative Agency/Official itself as a defendant or execution based on self respect. Where if the defendant is unwilling to carry out the verdict of the inkracht van gewisjde court, the relevant official/agency/institution is subject to payment of a forced amount of money or administrative sanctions. So that whether or not the court's decision on the inkracht is carried out is entirely left to the awareness and good intentions of the defendant himself (self respect).

The law both the Administrative Court Law and the Government Administration Law also do not regulate who carried out the execution. In the civil procedural law it is very clearly determined which organs or institutions are obliged to carry out executions under the orders and leadership of the Chair of the District Court. Not so in state administrative court procedural law. Neither the Administrative Court Law nor the Government Administration Act does not regulate and determine which organs or institutions will carry out the executions. Whereas regarding the execution of the decision (execution), the procedural law clearly provides provisions regarding the procedure for legal instruments in the framework of execution, such as: confiscation institutions, auctions, emptying and surrender. In the state administrative court procedural law, there is no such regulation, because in a state administration dispute there is no real execution, only administrative execution.

For additional obligations, namely the obligation of the defendant to pay compensation and carry out rehabilitation, theoretically, the execution can take place. Nevertheless, it is still unclear who led the execution. Implementation also depends very much on government organs. The element of coercion as a characteristic of execution is not apparent, so potentially there is a possibility of being unworkable. This shows the existence of legal obscurity (blurred norms) regarding because it gives room for uncertainty. This legal obscurity is also motivated by the absence of legal vacuum mentioned above. On the other hand the amount of compensation and compensation that the claimant can get is relatively small. As Article 3 Paragraph (1) of Government Regulation No. 43 of 1991, the amount of compensation can be obtained by the plaintiff, which is a minimum of two hundred and fifty thousand rupiahs and a maximum of five million rupiahs. The amount is certainly not proportional to the amount of compensation in civil cases that are not normatively limited.

That the Decree of the State Administrative Court is binding on the parties to the dispute (inter partes) as well as binding on everyone (erga omnes). According to Bagir Manan, erga omnes decisions have the advantage of having legal certainty over state administrative decisions sued in the State Administrative Court, while the other side is viewed negatively, making the State Administrative Court Judge, besides performing the judicial function by establishing the law, but also has widened to carry out the function of legislation by forming laws. 
The legal certainty of the Decree of the State Administrative Court, which is erga omnes, is not followed by certainty over its implementation. Provisions regarding the execution regulated in Article 116 Paragraph (4) of the Law on State Administrative Court, although it has stipulated the forced money or administrative sanctions, is only summarized. The unclear regulation regarding forced efforts and forced money reflects the lack of legal certainty regarding the execution of the state administrative court decision. Indicators of the absence of legal certainty include ${ }^{36}$ first, the unclear application of forced money (dwangsom), which still requires implementing regulations related to procedures and mechanisms for the payment of forced money; the unclear time or when can be determined the amount of forced money that must be paid; and it is unclear whether the imposition of forced money, whether charged to the agency/institution/administrative officer or the personal government official. Second, the unclear implementation of administrative sanctions that is not yet clear what types of sanctions can be applied; it is not clear about the basic regulations regarding administrative sanctions that can be used as a reference; and the mechanism and procedures for implementing administrative sanctions are not yet clear.

After the entry into force of the Government Administration Law, specifically Article 54, is related to the implementation of a positive fictive principle, because the silence of the Agency/Institution/State Administration Officer is considered approval, if the request for acceptance of the ruling by the applicant is granted, the Administrative Court then determines the decision to accept the request. Obligations that must be carried out by the related Agency/Institution/Official are then to determine the decision to implement the decision to accept the application by the Court. The decision (by the State Administration Agency/Officer/Institution) to execute the decision to accept the application by the court is constitutive or declarative in nature. Referring to Article 17 number 2 of the Supreme Court Regulation No. 8 of 2017, if the Court accepts the petition for the decision to accept the petition to read the Petitioner's request and requires the Agency/Institution/ Government Official to issue a Decree/take action referring to the Petitioner's request. So the contents of the decision to accept the application by the Court in the Government Administration Act is an obligation for the Administrative Agency/ Institution/Official to issue a Decision/take Action.

The obscurity of forced efforts related to the execution of the execution was also experienced in the implementation of Article 81 Paragraph (2) of the Government Administration Act. The forced effort is closely related to the execution of the decision to accept the application based on the implementation p. 139. 
of a positive fictive principle that was not carried out by the state administrative body/official. Where sanctions in the Government Administration Act are basically similar to sanctions as for the State Administrative Court Act that is forced money (dwangsom) or temporary dismissal with/without obtaining office rights.

Regarding forced money, there are no implementing regulations related to the procedures and mechanism for the payment of forced money that regulates the procedure for imposition, both time, the amount of forced money to be paid and related to the subject of imposition of forced money, whether charged to the agency/administrative officer or to the person of the Administrative official. As well as the temporary dismissal, there are no specific implementation rules yet so that this effort cannot be implemented.

From this description, the lack of legal certainty related to execution in the State Administrative Court Law. In addition to the revocation of the State Administrative Decree as referred to in Article 97 Paragraph (9) letter a of the State Administrative Court Act, for which automatic execution applies as stipulated in Article 116 Paragraph (2) of the State Administrative Court Law, the execution of execution in Administrative Court is basically again, it depends on the awareness and good intentions of the state administrative body/officials to carry out the content of the decision in a self respect manner which results in legal uncertainty. That is because only the state administrative body/officials can carry out the contents of the decision. In addition, forced efforts to encourage the implementation of the contents of the decision are also unclear, so the regulations cannot be implemented.

The public interest will potentially be greatly harmed because in terms of the execution provisions of the state administrative court decision the execution of the execution is related to the defendant's obligation to issue a state administrative decision depending on the will or good will of the defendant. The forced effort as an effort related to the execution of the court's decision cannot be realized. So if the defendant is reluctant/does not implement the contents of the decision, the execution of the state administrative court's decision cannot be carried out.

\section{CONCLUSION}

Based on the study examined in this paper, it can be concluded that the verdict of the state administrative court can be executed is the verdict of the state administrative court inkracht van gewisdje (which has permanent legal force) and is condemnatoir. There are two things that require the execution of the defendant's obligations related to the revocation of the Decree and the defendant's obligations related to the issuance of the State Administration Decree and/or taking action. The obligation is accompanied by the imposition of compensation and the provision of rehabilitation. The provisions of execution of the execution of the decision 
related to the obligations of the defendant to revoke the decision are sufficient, through the provisions of automatic execution. On the other hand there is a legal vacuum related to the provisions of the execution of the decision containing the defendant's obligation to issue a new and replacement state administration decision. The legal vacuum is because the unclear regulation regarding forced efforts and forced money reflects the lack of legal certainty regarding the execution of execution in state administrative courts.

Constraints faced in the implementation of the execution of the decision of the Administrative Court after the enactment of the Government Administration Act are still the same as before the enactment of the law. Where there are four things that become obstacles, namely who orders and leads the execution, who carries out the execution, and how the procedures are carried out, the law does not regulate and then the implementation cannot be forced because it is highly dependent on government organs. The element of coercion as a characteristic of execution is not apparent, so potentially there is a possibility of being unworkable. Because the execution of the Administrative dispute is still based on self respect, and due to unclear rules both in the Administrative Court Law and the Government Administration Law and the absence of implementing regulations related to forced efforts, the defendant's obligation to carry out his obligation to issue state administrative decisions cannot be forced, so that potentially could not be implemented, causing legal uncertainty. That is because the rights of the people contained in the state administration court ruling that inkracht van gewisjde cannot be realized. So that people do not get legal certainty in terms of the provisions and implementation of the execution of the State Administrative Court which is their right.

\section{REFERENCE}

Astomo, Putera. (2014). Eksistensi Peradilan Administrasi dalam Sistem Negara Hukum Indonesia. Masalah-Masalah Hukum, Universitas Diponegoro, 43(3), 363 - 371. doi: https://doi.org/10.14710/mmh.43.3.2014.363-371

Bedner, Adriaan. (2013). Indonesian Legal Scholarship and Jurisprudence as an Obstacle for Transplanting Legal Institutions. Hague Journal on the Rule of Law, Cambridge University Press, 5(2), 253 - 273. doi: https://doi.org/10.1017/S1876404512001145

Bunga, Marten. (2018). Tinjauan Hukum Terhadap Kompetensi Peradilan Tata Usaha Negara dalam Menyelesaikan Sengketa Tanah. Gorontalo Law Review, Universitas Gorontalo, 1(1), 39 - 49. doi: https://doi.org/10.32662/golrev.v1i1.155

Butt, Simon. (2013). Freedom of Information Law and Its Application in Indonesia: A Preliminary Assessment. Asian Journal of Comparative Law, Cambridge University Press, 8(1), 1 - 42. doi: https://doi.org/10.1017/S2194607800000879 
Choudhury, Nafay. (2017). Revisiting Critical Legal Pluralism: Normative Contestations in the Afghan Courtroom. Asian Journal of Law and Society, Cambridge University Press, 4(1), 229 - 255. doi: https://doi.org/10.1017/als.2017.2

Effendi, Maftuh. (2014). Peradilan Tata Usaha Negara Indonesia Suatu Pemikiran ke Arah Perluasan Kompetensi Pasca Amandemen Kedua Undang-Undang Peradilan Tata Usaha Negara. Jurnal Hukum dan Peradilan, Mahkamah Agung RI, 3(1), 25 - 36. doi: http://dx.doi.org/10.25216/JHP.3.1.2014.25-36

Government Regulation of the Republic of Indonesia Number 43 of 1991 concerning Compensation and Procedure for Implementation in State Administrative Court. State Gazette of the Republic of Indonesia, Number 52 of 1991. Supplement to the State Gazette of the Republic of Indonesia, Number 3448.

Gusman, Delfina. (2010). Efektifitas Pelaksanaan Upaya Paksa Putusan Pengadilan Tata Usaha Negara yang telah Berkekuatan Hukum Tetap. Masalah-Masalah Hukum, Universitas Diponegoro, 39(3), 221 - 230. doi: https://doi.org/10.14710/ mmh.39.3.2010.221-230

Hadjon, Philipus M. (2015). Peradilan Tata Usaha Negara dalam Konteks UndangUndang No. 30 Th. 2014 tentang Administrasi Pemerintahan. Jurnal Hukum dan Peradilan, Mahkamah Agung RI, 4(1), 51 - 64. doi: http://dx.doi.org/10.25216/ JHP.4.1.2015.51-64

Harahap, Zairin. (2009). Hukum Acara Peradilan Tata Usaha Negara. Jakarta: PT. Raja Grafindo Persada.

Harjiyatni, Francisca Romana, \& Suswoto, Suswoto. (2017). Implikasi Undang-Undang Nomor 30 Tahun 2014 tentang Administrasi Pemerintahan terhadap Fungsi Peradilan Tata Usaha Negara. Jurnal Hukum Ius Quia Iustum, Universitas Islam Indonesia Yogyakarta, 24(4), 601 - 624. doi: https://doi.org/10.20885/iustum.vol24.iss4.art5

Hayat, Hayat. (2015). Keadilan sebagai Prinsip Negara Hukum: Tinjauan Teoritis dalam Konsep Demokrasi. Padjadjaran: Jurnal IImu Hukum (Journal of Law), Universitas Padjadjaran, 2(2), 388 - 408. doi: https://doi.org/10.22304/pjih.v2n2.a10

Jiwantara, Firzhal Arzhi, Adolf, Huala, Wibowo, Gatot Dwi Hendro, \& Cahyowati, R. R. (2018). The Extension of Absolute Competence of State Administrative Court after the Enactment of Act Number 30 of 2014 on Government Administration in Indonesia. Journal of Legal, Ethical and Regulatory Issues, Allied Business Academies, 21(1), 1 - 11 . 
Jr., Dominic J. Nardi. (2018). Can NGOs Change the Constitution? Civil Society and the Indonesian Constitutional Court. Contemporary Southeast Asia, ISEAS - Yusof Ishak Institute, 40(2), 247 - 278. doi: https://doi.org/10.1355/cs40-2d

Law of the Republic of Indonesia Number 5 of 1986 concerning State Administrative Court. State Gazette of the Republic of Indonesia, Number 77 of 1986. Supplement to the State Gazette of the Republic of Indonesia, Number 3344.

Law of the Republic of Indonesia Number 9 of 2004 concerning Amendment to Law No. 5 of 1986 concerning State Administrative Court. State Gazette of the Republic of Indonesia, Number 35 of 2004. Supplement to the State Gazette of the Republic of Indonesia, Number 4380.

Law of the Republic of Indonesia Number 48 of 2009 concerning Judicial Power. State Gazette of the Republic of Indonesia, Number 157 of 2009. Supplement to the State Gazette of the Republic of Indonesia, Number 5076.

Law of the Republic of Indonesia Number 51 of 2009 concerning Second Amendment to Law No. 5 of 1986 concerning State Administrative Court. State Gazette of the Republic of Indonesia, Number 160 of 2009. Supplement to the State Gazette of the Republic of Indonesia, Number 5079.

Law of the Republic of Indonesia Number 12 of 2011 concerning the Formation of Legislation. State Gazette of the Republic of Indonesia, Number 82 of 2011. Supplement to the State Gazette of the Republic of Indonesia, Number 5234.

Law of the Republic of Indonesia Number 30 of 2014 concerning Government Administration. State Gazette of the Republic of Indonesia, Number 292 of 2014. Supplement to the State Gazette of the Republic of Indonesia, Number 5601.

Lotulung, Paulus Effendi. (2013). Hukum Tata Usaha Negara dan Kekuasaan. Jakarta: Salemba Humanika.

Lubna, Lubna. (2015). Upaya Paksa Pelaksanaan Putusan Pengadilan Tata Usaha Negara dalam Memberikan Perlindungan Hukum kepada Masyarakat. Jurnal lus: Kajian Hukum dan Keadilan, Universitas Mataram, 3(1), 159 - 171. doi: http://dx.doi. org/10.12345/ius.v3i7.205

Mawardi, Irvan. (2016). Paradigma Baru PTUN: Respon Peradilan Administrasi terhadap Demokratisasi. Yogyakarta: Thafa Media.

Petroski, Karen. (2013). Legal Fictions and the Limits of Legal Language. International Journal of Law in Context, Cambridge University Press, 9(4), 485 - 505. doi: https://doi.org/10.1017/S1744552313000268 
Putrijanti, Aju. (2015). Kewenangan serta Obyek Sengketa di Peradilan Tata Usaha Negara Setelah Ada UU No. 30/2014 tentang Administrasi Pemerintahan. MasalahMasalah Hukum, Universitas Diponegoro, 44(4), 425 - 430. doi: https:// doi.org/10.14710/mmh.44.4.2015.425-430

Rafiqi, Rafiqi. (2017). Kompetensi Pengadilan Tata Usaha Negara dalam Menyelesaikan Kasus Tanah tentang Hak Pengelolaan. JPPUMA: Jurnal IImu Pemerintahan dan Sosial Politik UMA (Journal of Governance and Political Social UMA), Universitas Medan Area, 5(2), 108 - 115. doi: http://dx.doi.org/10.31289/jppuma.v5i2.1207

Regulations of the Supreme Court of the Republic of Indonesia Number 5 of 2015 concerning Guidelines for Procedures for Obtaining a Decision on Acceptance of Requests to Obtain Decisions and/or Actions of Government Agencies or Officers. State Gazette of the Republic of Indonesia, Number 1268.

Regulations of the Supreme Court of the Republic of Indonesia Number 8 of 2017 concerning Guidelines for Procedures for Obtaining a Decision on Acceptance of Requests to Obtain Decisions and/or Actions of Government Agencies or Officers. State Gazette of the Republic of Indonesia, Number 1751.

Rodding, Budiamin. (2017). Keputusan Fiktif Negatif dan Fiktif Positif dalam Peningkatan Kualitas Pelayanan Publik. Tanjungpura Law Journal, Universitas Tanjungpura, 1(1), 26 - 37. doi: http://dx.doi.org/10.26418/tlj.v111.18328

Rumadan, Ismail. (2012). Problematika Eksekusi Putusan Pengadilan Tata Usaha Negara. Jurnal Hukum dan Peradilan, Mahkamah Agung RI, 1(3), 435 - 462. doi: http:// dx.doi.org/10.25216/JHP.1.3.2012.435-462

Simanjuntak, Enrico. (2014). Prospek Ombudsman Republik Indonesia dalam Rangka Memperkuat Pelaksanaan Eksekusi Putusan Peradilan Tata Usaha Negara. Jurnal Hukum dan Peradilan, Mahkamah Agung RI, 3(2), 163 - 176. doi: http://dx.doi. org/10.25216/JHP.3.2.2014.163-176

Soleh, Mohammad Afifudin. (2018). Eksekusi terhadap Putusan Pengadilan Tata Usaha Negara yang Berkekuatan Hukum Tetap. Mimbar Keadilan, Universitas 17 Agustus 1945 Surabaya, 11(1), 18 - 46. doi: https://doi.org/10.30996/mk.v0i0.1604

Sonata, Depri Liber. (2014). Metode Penelitian Hukum Normatif dan Empiris: Karakteristik Khas dari Metode Meneliti Hukum. Fiat Justisia: Jurnal IImu Hukum, Universitas Lampung, 8(1), 15 - 35. doi: https://doi.org/10.25041/fiatjustisia.v8no1.283 
Sudarsono. (2011). Pilihan Hukum dalam Penyelesaian Sengketa Tata Usaha Negara di Pengadilan Tata Usaha Negara. In I Gede Yusa (Ed.), Demokrasi, HAM \& Konstitusi: Perspektif Negara - Bangsa untuk Menghadirkan Keadilan; "Kado untuk Sang Guru Prof. Dr. I Dewa Gede Atmadja, S.H., M.S. Malang: Setara Press.

Suhariyanto, Budi. (2019). Urgensi Kriminalisasi Contempt of Court untuk Efektivitas Pelaksanaan Putusan Peradilan Tata Usaha Negara. Jurnal Konstitusi, Mahkamah Konstitusi RI, 16(1), 192 - 211. doi: https://doi.org/10.31078/jk16110

Sunge, Maisara. (2009). Efektivitas Eksekusi Putusan Pengadilan Tata Usaha Negara. Jurnal Inovasi, Ikatan Mahasiswa Pascasarjana dan Alumni Gorontalo di Bandung, 6(4), $70-83$.

Untoro, Untoro. (2018). Self-Respect dan Kesadaran Hukum Pejabat Tata Usaha Negara Menuju Keadilan. Pandecta: Jurnal Penelitian Ilmu Hukum (Research Law Journal), Universitas Negeri Semarang, 13(1), 37 - 49. doi: https://doi.org/10.15294/ pandecta.v13i1.7856

Wahyunadi, Yodi Martono. (2016). Kompetensi Absolut Pengadilan Tata Usaha Negara dalam Konteks Undang-Undang Nomor 30 Tahun 2014 tentang Administrasi Pemerintahan. Jurnal Hukum dan Peradilan, Mahkamah Agung RI, 5(1), 135 154. doi: http://dx.doi.org/10.25216/JHP.5.1.2016.135-154

Wairocana, I Gusti Ngurah, Sudiarta, I Ketut, Layang, I Wayan Bela Siki, Sudiarawan, Kadek Agus, \& Pramana, I Gede Pasek. (2019). The Expansion of Administrative Decision Meaning Based on Government Administration Law: A Dispute Submission Process Approach. Jurnal Magister Hukum Udayana (Udayana Master Law Journal), Universitas Udayana, 8(1), 13 - 33. doi: https://doi.org/10.24843/ JMHU.2019.v08.i01.p02

Wijayanta, Tata. (2014). Asas Kepastian Hukum, Keadilan dan Kemanfaatan dalam Kaitannya dengan Putusan Kepailitan Pengadilan Niaga. Jurnal Dinamika Hukum, Universitas Jenderal Soedirman, 14(2), 216 - 226. doi: http://dx.doi. org/10.20884/1.jdh.2014.14.2.291

Yulianto, Eko. (2017). Hukum Acara dan Praktek Peradilan Tata Usaha Negara. In Pendidikan Khusus Profesi Advokat. Yogyakarta: Indonesian Advocates Association (PERADI) in collaboration with Gadjah Mada University.

Yulius, Yulius. (2018). Diskursus Lembaga Eksekusi Negara dalam Penegakan Hukum di Indonesia. Jurnal Hukum Peratun, Mahkamah Agung RI, 1(1), 11 - 32. 
Yusa, I Gede, \& Hermanto, Bagus. (2017). Gagasan Rancangan Undang-Undang Lembaga Kepresidenan: Cerminan Penegasan dan Penguatan Sistem Presidensiil Indonesia. Jurnal Legislasi Indonesia, Kementerian Hukum dan Hak Azasi Manusia $R I, 14(3), 313-323$.

Yusa, I Gede, et al. (2016). Hukum Tata Negara: Pasca Perubahan UUD NRI 1945. Malang: Setara Press.

Yuslim, Yuslim. (2015). Hukum Acara Peradilan Tata Usaha Negara. Jakarta: Sinar Grafika. 